\title{
14 HEALING HUMANKIND AND RITUAL ENTREPRENEURIALISM: THE FAITH OF UNITY RELIGION IN UGANDA
}

Asonzeh Ukah ${ }^{1}$

\section{INTRODUCTION}

The relationship between religion and human flourishing is a complex, complicated and even contradictory one. Human flourishing is a biological or ecosystems metaphor signifying healthy, holistic and harmonic growth and living. Different religions or religious groups create and generate diverse and dynamic salvific ecosystems for their adherents. This is especially so with new religions (or New Religious Movements, NRMs), many of which argue for their validity and veracity by presenting new ways of enhancing human existence or experiencing the sacred. Arguably, religious change in Africa is the most pervasive and visible form of social transformation on the continent, affecting every sphere of society. In recent years, there has been a dizzying proliferation of NRMs on the continent, within and across religious traditions. The emergence of NRMs is instigated by a diversity of variables, some of which represent a mixture of religious, social, political, economic and organisational innovation, creativity and interpretations of the human condition. Frequently, these movements and their founders or leaders promise their societies (or the entire world) new revelation(s), visions of life, eschatological truths, perspectives or interpretations about the value, purpose and meaning of human existence. Creativity and innovation within NRMs significantly relate to novel insights into ways of being human, being in the world and living an optimal lifestyle. In other words, human flourishing - both ordinary and transcendental - is an important agenda for religious groups. This is the case with the Faith of Unity (FoU) religious organisation in Uganda, whose leader and founder, Dosteo Bisaka, is popularly called by the honorific title Owobusobozi by followers. This chapter examines the history, doctrines and rituals of this group, paying critical attention to the analysis of its teaching and practices about healing as a key strategy to achieve and ensure human flourishing. ${ }^{2}$

1 Associate Professor, Department of Religious Studies, University of Cape Town.

2 Two phases of ethnographic fieldwork in FoU were done in 2016 and 2017 in Kampala, Kapyemi, Munteme and Kihuuru, all in Uganda. The author acknowledges funding support from the John Templeton Foundation through Nagel Institute for the Study of World Christianity project on "Religious Innovation and Competition: Their Impact in contemporary Africa", sub-project, "Miracle Cities: The Economy of Prayer Camps and the Entrepreneurial Spirit of Religion in Africa" (ID: 2016-SS350). The author thanks Omukama Ruhanga Owobusobozi Bisaka for granting permission to research FoU, as well as Livingstone Akugizibwe, Elder Tumuheire and Dr Janice Desire Busingye for assisting during fieldwork in Uganda and with translation from Runyoro to English. 
The popularity and expansion of FoU are an example of how the African religious landscape is constantly animated with new religious movements. ${ }^{3}$ While different forms of Christianity are socially and politically visible and powerful in different African societies, in Uganda and the wider East African Great Lakes Region, the honour of restructuring, reforming, re-ritualising or critiquing missionary Christianity goes to FoU, a religious organisation that creatively recouples health, healing and ritual as the primary assets - goods of salvation - to living a harmonious and flourishing life. FoU's unique salvific doctrine is that disunity amongst humanity is a disease that can be healed through the restoration of physical health to the human body. The key figure in that process of restoration is its leader, Owobusobozi. A key argument of this chapter is that the complex rituals of healing, in the worldview of FoU and its leader, are central to preparing individuals to live maximally and flourish in the world as a way of optimising their potential and capacity to work towards the Third Age of Oneness of humanity. This understanding informs the long hours of tactile rituals of healing in which the group engages regularly. Although FoU exists in tension with traditional African (specifically, Bunyoro) religious culture and practices, it also aims to recreate the Christian worldview and scripture in ways that strongly resonate culturally with its members.

\section{THE THIRD ERA OF UNITY AND HARMONY: DOSTEO OWOBUSOBOZI BISAKA}

The Faith of Unity is a religious movement officially founded on 22 February 1980 by Dosteo Bisaka in Kapyemi village in Muhorro town, which is in Kagadi district of western Uganda. Kapyemi is a small village nestled on a crust of a hill surrounded in lush greenery and scenic environment. The circumstances of the establishment of FoU are as dramatic as the biography of the founder: both trace their history to the disruptive presence of missionary Christianity in Uganda. ${ }^{4}$ Bisaka was born on 11 June 1930 into a staunchly Catholic family. Both his father, Petero Byombi, and his grandfather, Alifonsio Wenkere, were catechists in their local Catholic parish church at Bujuni. It was the same religious role Bisaka would occupy in the future, a fact that is significant in the establishment of FoU. Bisaka's mother was Agnes Kabayoora and his grandmother was Martha Nyakake. Very little is known of Agnes; however, Martha played a profound role in the life of young Bisaka

3 Ukah A. 2018. "Emplacing God: The Social Worlds of Miracle Cities - Perspectives from Nigeria and Uganda", Journal of Contemporary African Studies 36(3):351-368; Ukah A. 2018. "'Everything is Plastic': The Faith of Unity Movement and the Making of a Post-Catholic Religion", Journal for the Study of Religion 31(2):138-160.

4 Although it was founded more than three decades ago, there was a dearth of published research on FoU until recently, following my ethnographic research on the movement. See Ateenyi MP. 2000. "New Religious Movements in Post-Independent Uganda", PhD Diss, Makerere University; Akugizibwe J. 2012. “Social Impact of Owobusobozi Bisaka's Religious Movement on Nyoro Culture: A Case Study of Muhorro Sub-County, Kibaala District", BA Diss, Makerere University; Ukah, "Everything is Plastic". 
and had a more lasting influence in the outlook on life and the doctrines of FoU decades in the future. At the age of eight, Bisaka left his parents and lived with his grandparents. It was unclear why he moved in with his grandparents; however, the pressure of his grandfather's and father's work as catechists could have contributed to this situation. While with his grandparents, Bisaka was particularly close to his grandmother Martha who "used to teach him a lot about the goodness of God. The words he was taught stayed in His mind for a long time. And both grandparents of his loved Him very much, Him being an obedient child, who was, as well, looking after their cattle." ${ }^{5}$ More importantly for young Bisaka, the grandmother, a witness to and a victim of the violence of religion in the late-eighteenth century which resulted in the famous Ugandan martyrs, ${ }^{6}$ socialised Bisaka not only into the rituals of the Catholic church, but also into the narratives of the dysfunctional features of missionary Christianity. According to Bisaka, his grandmother Martha "had witnessed Charles Lwanga and other Uganda martyrs being burnt because she was captive staying at the Mengo palace", ${ }^{7}$ an experience or narrative that must have made a deep and indelible impression on the mind of impressionable Bisaka.

Bisaka fondly recalls the influence of his grandmother in the formation of his spiritual desires and quests. For example, while enrolled in Mugalike School, "the idea of becoming a [Catholic] priest remained in Him due to the teaching of His grandmother". ${ }^{8}$ Bisaka's Catholic background and the intense devotion of both his parents and grandparents instilled in him a desire for the Catholic priesthood. Becoming a priest would have surpassed the devotion and commitment of both his father and grandfather, who were catechists. A priest, for Bisaka, stood in a special

5 Bisaka D. 1987. The Book of God of the Age of Oneness: We are One in the Lord God of Hosts Disunity has Ended. Kapyemi: Faith Unity Publications, 7.

6 The first Catholic converts in Uganda (or more specifically Buganda) were baptised in 1882 by the White Fathers missionaries. The King of Buganda, Mutesa, known by the title of Kabaka, died in 1884 and was succeeded by his heir, Mwanga. By the following year, the crisis has been ignited through what Christian missionaries claimed was Mwanga's "unnatural desires" for young Christian pages or readers serving in the king's court. In 1885, Bishop Hannington was killed on the order of the King, who, in September 1886, further demanded that the Christian pages in his court recant their new faith; those who refused to do so, numbering more than 30 , were "burned alive on a single funeral pyre at Namungogo". The controversies surrounding "kingly or royal sex" with subjects, homosexuality and the role of missionary Christianity in uncoupling indigenous political institutions and cultures caused so much disruption and disunity in Buganda (and many other places in Africa), a point that Bisaka was to emphasise in his doctrines and practices 92 years after. Such massive disruptions could be rightly characterised as sacral trauma. The theory of sacral trauma explains the emergence of new religious movements in Africa as a response to individual and collective problems and conflicts demanding solutions, which are not offered by existing religio-cultural systems. Religious movements, such as FoU, are social movements responding to collective trauma caused by the disruption of the African worldview and its way of life by the violence of missionary (Christian and Islamic) religions and European imperialist and colonial interventions.

7 Bisaka, Book of God, 7.

8 Bisaka, Book of God, 7. 
mediatory role, inscribed with more significant responsibilities as a sacred specialist than a catechist. In 1944, therefore, he sought admission to the diocesan junior seminary for the training of Catholic clergy. He failed to get admitted, but there was no specified reason for his rejection, which could have been because of a range of factors, such as below average academic performance. However, when Bisaka finished with Mugalike School, he enrolled in Nsamizi Teacher's College, Mityana, from where he graduated with a Grade III Teachers Certificate, qualifying him as a school teacher. With his new qualification, Bisaka was hired by the Catholic Diocese of Hoima to teach at the Catholic Primary School at Muhorro, where he worked for 35 years.

Bisaka's failure to train for the Catholic priesthood did not dampen his spiritual enthusiasm and desire to serve in different capacities within the Catholic Church. As a gifted singer, he soon became choirmaster of Muhorro Catholic Parish, the neighbourhood where he was employed. In addition to this role, he became the secretary to the Muhorro Catholic parish and the spiritual counsellor and advisor to the Confraternity of the Legion of Holy Mary Mother of Grace. As time passed, he left the secretary's position and became the Chairperson of the Parish Council, a lay position of enormous responsibility and prestige. His religious profile increased when the diocesan ordinary, bishop Albert Edward Baharagate of the Catholic diocese of Hoima appointed him into the Diocesan Liturgical Committee. ${ }^{9}$ This was a clear recognition of his musical gift and contribution to the liturgical life and rituals of the local Catholic community.

Key to the ritual significance or self-awareness of Bisaka, as well as the founding of FoU, is the composition of liturgical songs and music which commenced in 1966. Some of his musical compositions, such as "Guba Mugisa Kuteranizibwa" (Holy Matrimony is a Lucky institution), ${ }^{10}$ were included in the Rutooro Catholic Hymnal. Bisaka's active participation in the religious life of his community brought him local renown, and he got numerous invitations from parish priests around the diocese to hold music seminars for parish choirs, including some priests and nuns. The director of religious studies at the diocesan schools once had Bisaka conduct a five-day seminar on liturgical hymns at Mugalike parish. At the end of the seminar, the nun in charge of the school cited St. Augustine's word to the effect that "He who sings, prays twice"11 in her attempts to emphasise the importance

9 Bishop AE Baharagate was the bishop of Hoima diocese from 5 October 1969 until 9 March 1991.

10 This is a hymn that underscores the value and spiritual significance of the sacrament of holy matrimony.

11 This saying is found in the Catechism of the Catholic Church (CCC), art 1156. However, the saying, either in the two possible Latin translations of "qui canit bis orat" (he who sings prays twice) or "qui bene cantat bis orat" (he who sings well prays/praises twice) does not appear in the Confessions. The closest one can get to attributing this saying to St. Augustine is to be found in his commentary on Psalm 73:1: Qui enim cantat laudem, non solum laudat, sed etiam hilariter laudat ("For he that sings praise, not only praises, but only praises with gladness: he that sings praise, not only sings, but also loves him of 
and ritual value of Bisaka's musical gift and composition. He received various words of encouragement, appreciation and monetary gifts from grateful priests, including Bishop Baharagate, for his religious work in the diocese. The widespread acknowledgments of his contribution caused some members of the local clergy to interpret his gift as a unique vocation, a divine election or sacred office: "God chose you", a priest once told him. ${ }^{12}$ His liturgical contribution became so recognised that the bishop of Hoima recommended "sending him to further studies in music", but he was unable to follow through on the offer and he did not give reasons for his decision. ${ }^{13}$

Consistent with the character of charisma, Bisaka attributed his "gift" of musical composition to a superior power beyond his limited learning or capability. He claimed that his songs and the musical notes came to him effortlessly without "search[ing] for it"; 14 he received them through "special inspiration". Such a claim makes Bisaka look upon himself as a divine receptacle, a vessel made ready through decades of teaching under his Catholic grandparents and catechist father as well as years of active participation in fashioning a vibrant liturgical life for the Catholic community of Runyoro. His career as a composer of ritual music came to a head in 1975, with the composition of a song that marked a turning point in his religious life and self-understanding as a religious leader. In that year, he composed a song he titled "Nkaikiriza Ruhanga Murungi" (My God is Good). ${ }^{15}$ Made of 24 short verses or sentences, the "Nkaikiriza" was an unusually popular song which became a favourite of many parish choirs who used it in the Catholic Mass. When this song was used in church during the Eucharistic celebration, Bisaka claimed certain bodily sensation would start to occur around his arms and hands. With time, the chanting of "Our Lord's Prayer" during liturgy started producing similar bodily sensation as the "Nkaikiriza". As a laity, he was unsure how to interpret his mystical experience of "there started coming to His arms a special kind of power whenever He would sing it in church", but some church leaders he confided in informed him it was as a result of the praises he composed in the "Nkaikiriza".

Bodily sensations during worship went on for five years. In late 1979, he claimed to have heard a voice "commanding Him, 'You shall heal people by touching them'" ${ }^{16}$ While the voice was persistent over a number of times, he ignored it for three months for fear of not knowing how to proceed, that is, how to utilise or unpack

whom he sings. In praise, there is the speaking forth of one confessing; in singing, the affection of one loving"), an attribution which a different edition of the CCC accurately made. See St. Aurelius Augustine. 2007. Expositions on the Psalms. Hildebrandt T (comp.). Online at: https://faculty.gordon.edu/hu/bi/ted_hildebrandt/otesources/19-psalms/text/ books/augustine-psalms/augustine-psalms-web.htm [Accessed 19 April 2019].

Bisaka, Book of God, 9.

Bisaka, Book of God, 8.

Bisaka, Book of God, 9.

A translation of the song is found in Ukah, "Everything is Plastic", 145.

Bisaka, Book of God, 10 (emphasis in original). 
such an instruction, but more importantly, for not knowing how his employer, the Catholic Church, a dominant and powerful social institution in western Uganda at the time, would relate to such phenomenon should he make it public. All the trepidation and uncertainty vanished on 22 February 1980, when he mustered courage and "accepted and touched a [sick] person and the person became healed! From there He proceeded with the work of saving people from diseases of different types". ${ }^{17}$ The $u$-patient, the first person Bisaka touched and restored to health in the inaugural act that ignited his healing mission, was a young woman, known as Mitorro, ${ }^{18}$ who was suffering from high fever attributed to malarial attack. ${ }^{19}$ That same act was also an epiphany of the Third Age of Oneness, which represents human redemption with Bisaka as the principal dramatis personae. Effectively, this date of touching and healing a sick a young woman is celebrated in FoU as the effective date of the establishment of the organisation, although it did not take the name of the "Association for the Healing Place of God of All Army" until much later.

Faith of Unity is an organisation whose members are easily socially set apart and identified by their liturgical gowns, a white overall called kanzu, which is secured at the waist by a thin white belt or sash made of the same fabric as the kanzu, called kitara. According to elders of the group, the kanzu symbolises holiness or heaven, while the kitara is regarded as a belt or girdle that secures a sword with which a member battles Satan or his minions. Members' kanzu is made of cotton, while that of the leader is made from silk, and the leader's kitara is broader than those of members, like the cincture of bishops and knotted on the right-hand side. The leader carries a long white stick, white crozier, a pastoral staff, in his right hand during ritual events; the stick symbolises his role as a shepherd and a king. He alone wears shoes or sandals inside the Itambiro, the Hall of Healing or within the sacred ground of Kkapyemi Camp. Generally, subordinates kneel before superiors, but everyone kneels before Bisaka as a mark of respect and acknowledgment of honour. While in the kneeling position, the superior person touches with the right hand the shoulder of the one kneeling as a tactile gesture of acknowledgment. The corporate colours of FoU are white and yellow or gold. ${ }^{20}$ While white symbolises holiness, yellow symbolises royalty. The motto of the group is "Obumu nigo mani", Runyoro for "Unity is Power". It signifies the primary organisational goal of the association, which is the dissolution of disunity and materialisation of "the Age of Oneness". ${ }^{21}$

17 Bisaka, Book of God, 10.

18 Members of FoU bear single names, dispensing with surnames as unnecessary European introduction. Mitorro, who was still alive in 2016 and 2017 during fieldwork, was usually a showcase during Bisaka's important celebrations.

19 Malaria is endemic in western Uganda. In the country as a whole, "it accounts for $25-40 \%$ of all outpatient visits at health facilities and $20 \%$ of all hospital admissions". Katuura EP, Waako P, Ogwal-Okeng J and Bukenya-Ziraba R. 2007. "Traditional Treatment of Malaria in Mbarara District, Western Uganda", African Journal of Ecology 45(1):48.

20 These are the same corporate colours of the Vatican City-State, pointing to the combinative tendencies of FoU.

21 According to Ateenyi, the group has a different motto: "We are one in the Lord God of Hosts. Disunity has ended" (Ateenyi, "New Religious Movements in Post-Independent 
There are three sacred days of ritual obligation, which are the second, twelfth and twenty-second of each month. While insisting that every day is a day of salvation, these three days are described as "The days on which the Lord God performs miracles of saving all people from Satan, the enemy, and from their diseases" ${ }^{22}$ The group has a unique form of greeting: when a member meets another, one intones loudly, "Disunity", while the other responds, "has ended". This formula is at the heart of the theology of healing of the group, as shall be discussed shortly.

\section{ILLNESS CAUSATION, HEALING AND HEALTH}

\section{Sources of illness}

As the reconstruction of the founding of FoU demonstrates, the organisation's core concern is to bring "healing" to people who are sick and burdened by disease. Healing is imparted through physical touch, but this is not the only means by which health-seekers are restored to health. Because FoU is a healing movement, the founder acquired an 87-acre piece of land on which he constructed his operating base, the control and command centre of the group and his permanent residence. The two most prominent structures within this "Healing City" are the Itambiro (plural Amatambiro), which is a gigantic place of worship capable of accommodating between 1,500 and 2,000 worshippers, ${ }^{23}$ and the Palace of Bisaka, where he lives with his three wives. ${ }^{24}$ Both structures were built through collective efforts of the followers and members of the organisation and commemorate the importance that the group attaches to both healing and the prime healer, Bisaka.

FoU is founded on healing and an elaborate understanding of illness causation, which is mainly set out in its scripture. On 23 December 1983, Bisaka had a mystical experience which further transformed his self-understanding. According to Bisaka, "He went to the Lord God of Host and saw for Himself His true figure [nature] and the magnitude of the power which makes Him overcome various kinds of problems such as Satan and others." 25 According to the interpretation of elders of the group, this cryptic reference is understood to mean that Bisaka died and after three days was resurrected and given the power to heal illness and fight Satan. ${ }^{26}$

Uganda", 67). This is very unlikely, because those two sentences are part of the title of the scripture of the group as written by Bisaka and a part of the new greeting formula introduced by the supreme leader.

22 Bisaka, Book of God, sec 142.

23 This Itambiro was inaugurated on 11 June 2005 by the Ugandan president, Yoweri Museveni.

24 Like the Itambiro, the Palace was officially inaugurated on 11 June 2015 by Yoweri Museveni. The dates of the opening of important buildings in FoU are scheduled to also commemorate the date of birth of the leader, 11 June.

Bisaka, Book of God, 18.

26 This transformational experience is generally interpreted by senior leaders of the group as "the experience of death and resurrection", an encounter that endowed Bisaka with 
Two years after this 1983 experience, Bisaka published the scripture of the group in Runyoro, the ritual and official language of FoU, Ekitabu Ekya Ruhanga Eky'Obusinge Obw'Obumu Tuli Bamu Omu Mukama Ruhanga Owamahe Goona Okwahukana Kuhoireho (1985). An English translation was released in 1987 as The Book of God of the Age of Oneness: We are One in The Lord God of Hosts - Disunity has Ended. This scripture, written in verses like the Bible or the Catechism of the Catholic Church, describes Bisaka as a sacred personality within a Triune Godhead, "The Lord God of the Power of God; who is to make people one, ... He is the one who is referred to as Omukama Ruhanga Owobusobozi Bisaka ... [who] is the Supreme Fighter in the Hosts of Angels of the Lord God of Hosts which is invincible ... He is the one who unites people." 27 The other members or persons within the Trinity of Godhead are "[t]he Lord God of Hosts ... who created everything" and "The Lord God of Holiness of God ... who cleanses all people". ${ }^{28}$ According to the official doctrine of FoU, Bisaka as Owobusobozi is "the true God" and "God in the flesh". ${ }^{29}$ It is in this status and capacity that he brings healing to the sick as persons and to humanity and the world as cosmic unity.

Broadly, in FoU there is a personalistic understanding of the sources of illness, such as bad human beings who have the means and intention to make others suffer ill heath. These include witches and sorcerers or wicked persons. These are people who use and bury "satanic medicines of all sorts" in their homes, gardens and farms, either to mystically fortify themselves or to hurt others. ${ }^{30}$ In a list of 23 items and questions enumerated in The Book of God, ${ }^{31}$ which members must review and answer prior to being admitted into the group's investiture hall, members are asked if they have had "any satanic medicines in my body" (Q.1) or are ordained to any local deities (Q.2) or ancestral spirits (Q.4) or use love charms on others (Q.5 \& 6). Members are

enormous powers that defy laws of nature and allows him to bilocate or appear to multiple followers in dreams, visions and apparitions (conversation with Senior Elder Tumuheire, 14 December 2018). The experience of death and resurrection is a pre-requisition, according to sec 42 of The Book of God, for postmortem appearance of a person. 
asked if they have destroyed "clan horn fetish (Ntogota)" which is believed to assist in biological reproduction "and the well being of all children in the clan" (Q.11). Performing or getting involved in rituals pertaining to warding off or appeasing deities causes illness. Specifically, the scripture mentions that withholding religious items or paraphernalia, such as the Bible or rosaries, is a source of illness, because these items "are the chwezi $i^{32}$ [which should be brought] to Owobusobozi to that He drives these gods away from them" (Q.22). Non-human spirits which cause illness include ancestral spirits or ghosts of dead people, evil deities, as well as a pantheon of mystical people, called Chwezi, who are believed to possess very powerful magic and who are the original owners of the Bunyoro. The Chwezi are believed to vanish into rocks and lakes and trees when they encounter humans. Satan, the great and supreme Tempter, torments humans through these spirits. ${ }^{33}$ Healing is a form of doing battle against Satanic forces, that is why Owobusobozi is cast in the image as the "Supreme Fighter" who does battle against omwohya, the Tempter.

FoU also recognises naturalistic explanations of illness, such as structural degradation of human beings, or accidents, such as being knocked over by the ubiquitous motorcycle taxis in the Kagadi. Of significance is the first act of healing which ignited Bisaka's mission and mandate; it was about a naturalistic illness: malarial attack. In both personalistic and naturalistic conceptions of illness, the patient is assumed to exercise a degree of agency and responsibility. This is the reason for the 23 articles of faith that are necessary for the examination of conscience before each worship meeting. Further, FoU believes that a person can "inoculate" him or herself (of their own accord) with demons of deities of "the Chweezi [also spelled Chwezi] type which claim to be prophets ... are inoculated into the bodies through cuts [that is, incisions] and they have even started making people buy rosaries, Bibles, prayer books and the books of psalms, and satans that tempt people and in some places which make them week, crying out, 'Jesus, Jesus' and yet they are telling lies". ${ }^{34}$ Those who are so inoculated with evil spirits need only come to

32 Chwezi are believed to be mythic people who ruled ancient kingdoms and dynasties that stretched across the East African Great Lakes Region, which included the Bunyoro empire. Historically, the Chwezi dynasty collapsed in the sixteenth century CE and was supplanted by the Luo kingdom. As mythic beings, the Chwezi are characterised as possessing great spiritual powers that make them partake in both human and underworld life. Traditional Bunyoro still believe that this mythic people still exist as gods in the underworld and are often offered sacrifices. See Oliver R. 1955. "The Traditional Histories of Bugunda, Bunyoro, and Nkole", Royal Anthropological Institute of Great Britain and Ireland 85(1/2):111-117; Stroeken K. 2006. "'Stalking the Stalker': A Chwezi Initiation into Spirit Possession and Experiential Structure", Journal of the Royal Anthropological Institute 12(4):785-802; Onyas WI, McEachern MG and Ryan A. 2018. "Co-constructing Sustainability: Agencing Sustainable Coffee Farmers in Uganda", Journal of Rural Studies 61:12-21.

33 While FoU denies burning the Bible, in the past it did incinerate Bibles, rosaries, other Christian paraphernalia, as well as amulets, charms and clan horns (amahembe) as a source of evil energy and unworthy of a member (Ateenyi, "New Religious Movements in Post-Independent Uganda", 72).

Bisaka, Book of God, sec 156. 
Bisaka and "all those [spirits] simply run away". ${ }^{35}$ The claim here is that illness can befall a person because of their actions, and an individual who invites evil and dirty spirits into their lives usually will experience some spiritual consequences. These spirits, however, "simply run away" before Owobusobozi, ${ }^{36}$ who is a more superior healing power.

On a global level, FoU believes that disunity, fractionalisation of the community, social, political and religious, is a cosmic illness. Healthy individuals cannot function at their optimal capacities within a fraught social, political and religious environment. Hence, Bisaka teaches his followers that a new age, called the "Third Age" or the "Age of Oneness" was inaugurated at his birth on 11 June 1930. This new dispensation became operational and active from 1966, when Bisaka started doing the work of redemption, first through the composition of liturgical hymns. According to a senior elder of the group, "the main purpose of the Faith of Unity is to proclaim the love of one another and the unity of all people", which were ruptured in the previous two ages. The first age was the age of barbarism, ignorance and lawlessness; the second age is the age of Christ and Christianity, which tried to repair the disunity in humanity, but inadvertently complicated the situation by introducing further disunity and religious factions, such as the creation of "cults" and "sects". ${ }^{37}$ Consequently, the first step to restoring human unity is to eradicate

35 Bisaka, Book of God, sec 156.

36 Bisaka, Book of God, sec 156.

37 FoU has a history of being characterised as a "sect" and a "cult" by popular media, both local and international, as well as by the mainline religious organisations, a term leaders of the group vehemently resent and detest. However, the leader used the term "sects" five times in its scripture, The Book of God, in its polemic to characterise other religious organisations (secs 91, 95, 97). "Sect", from the Latin "secta", meaning "branch", is used sociologically to characterise schismatic breakaway religious groups from mainline or dominant Judeo-Christian denominations. See Stark R and Bainbridge WS. 1979. "Of Churches, Sects, and Cults: Preliminary Concepts for a Theory of Religious Movements", Journal for the Scientific Study of Religion 18(2):113-131; Tinaz N. 2005. "A Social Analysis of Religious Organisations: The Case of Church, Sect, Denomination, Cult and New Religious Movements (NRMs) and Their Typologies", Islâm Araştirmalari Dergisi [Turkish Journal of Islamic Studies] 13:63-108. It can also be applied to a breakaway from a major religious organisation or tradition. FoU's abhorrence of being described as a "sect" is to demonstrate that it is an independent religious movement and not a breakaway faction of Catholicism or Christianity. Similarly, the concept and popular usage of "cult" is fraught with ambiguities and extreme negative connotations. From the Latin word "cultus", meaning "to care (for the deities)", the term is often used by members of the mainstream religions to describe marginal religious groups as "bad religion", which are harmful, deceitful, dangerous, extreme and exploitative of their members. According to Rodney Stark and Roger Finke, "cult" is frequently used to describe "religious groups outside of or somewhat marginal to the conventional [...] Judeo-Christian tradition [...]. For reasons that had much to do with politics but little to do with practices, brainwashing was viewed as the special province of cults." Stark R and Finke R. 2000. Acts of Faith: Explaining the Human Side of Religion. Berkeley: University of California Press, 136. As a former catechist, Bisaka must have known how his former church used the term to characterise its competition, depicting them as bad, harmful religions. He sees his movement, FoU, as an authentic 
the Bible, the sole instrument and purveyor of disunity and religious sects: "In order to unite all people into one flock under one shepherd, the Lord God of Hosts will first do away with the Bible, and then give them His new words which they will use in the Third Age." 38 When this goal is achieved, hatred and disunity will be vanquished from humanity, because the Tempter would have been removed from amongst the midst of humanity and all people will love one another. "All people will be very happy because of this age of good people." 39

One significant benefit of the Third Age is in the reconstitution of the institution of marriage and the family: "Because of having removed the tempter (satan) who had brought about hatred and disunity amongst people, they will now be marrying as many women as they wish, because ill-will is what brought about changes in marriages. Yet God's commandments did not put any limit to the number of women men can marry." 40 In FoU, men are permitted to have as many wives as they can take care of. According to elders of FoU, this practice is in accord with African tradition and it is also necessary to stem the consequences of prostitution. "Restricting a man to marrying only one woman so that many women go without, is to encourage prostitution. This is because those who remain without have to roam about, looking for support. As a result of this promiscuity, many of them contract dangerous diseases some of which are difficult to cure. They may even transmit such diseases to the married ones if any one of them contacts them." 41

The leader had four wives (one died in 2001). The first wife bore him 13 children. ${ }^{42}$ As single women are not permitted to refuse marriage advances from men, according to female research participants, the possibility of acquiring wives is a strong attraction of FoU to men in joining the group, but also actualising the

religion and even superior to Catholicism and Christianity as a whole. Bisaka, Book of God, 20. According to Bisaka, Book of God, the Bible is the source and cause of sectarian division and disunity. "Sect" and "cult" "have acquired a negative value connotation" (Clarke PB. 2006. New Religions in Global Perspectives: A Study of Religious Change in the Modern World. London: Routledge, 9), which the leadership of FoU is aware of; hence, the organisation decries being described as a cult or sect.

Bisaka, Book of God, 20 sec 80 (emphasis in original).

Bisaka, Book of God, sec 83.

Bisaka, Book of God, secs 200 and 201 (emphasis in original). Leaders of FoU are silent about the problems of attributing the causes or negative consequences of prostitution to women alone. Their priority, according to one of the elders, is not about social and gender equity, but about the new ethical, apocalyptic vision and programme which Bisaka reveals in The Book of God. That vision is to reconstitute the family and marriage institutions and restore ethical and existential harmony to an otherwise disrupted, disunited existence. Similarly, the organisation recognises the problem or possibility of the wealthiest men marrying the choicest or even all the available women in a given society, leaving poor men with none, but does not address it. Gender equity, social justice or equitable power and wealth distribution seem to be far-flung ideals and aspirations for the group.

42 As of 2016, he had 74 grandchildren and 137 great-grandchildren. He has no children from his three remaining wives. 
vision of the Third Age, which is to bring healing to human family and marriage institutions. Healing, both cosmic and personal, "is like a drum that summons people together in order to tell them of the good news of human unity". ${ }^{43}$

Illnesses that are attributed to personal failings, demonic or spirit possession creates "inefficiency" and inadequacies and so prevents people from performing at the peak of their skills, gifts and endowments. Specifically, illness compromises members' duty to devote "nine days of work to fight evil spirits while one day is dedicated to rest and worship of God". ${ }^{44}$ The inefficiency of sickness multiplies according to the levels and degrees of failed obligation to fulfil certain tasks, to perform work and to relate to others within one's family and society. Illness makes the sick fail to socialise with others. Sickness prevents the sick from communing and relating to their neighbours to the degree commensurate with their estate, skills, gifts and position in the society. According to Bisaka, he focuses on healing because, in addition to working according to a sacred mandate, sickness vitiates capacity for action and disrupts the ability of people to care for themselves and for others. Sickness also ruptures the harmony that needs to exist in society especially in ways that persons need to relate with others. Illness deprives a person of relevant capacity for achieving self-fulfilling objectives and obligations. Illness makes the sick person unable to share themselves and their material resources, either because they cannot produce these resources, or they are instead invested in seeking health. Sickness distorts, thwarts and disrupts the capacity of a person to realise their destiny because it makes it difficult and, in some cases, impossible for persons to carry out their God-assigned duties in life. ${ }^{45}$ The responsibility which God gives to humans is compromised or undermined by illness and diseases, Satan and his demons, such as evil spirits or Chwezi. ${ }^{46}$ Above all, sickness makes it hard for humans to fulfil the "duty to pray to God". ${ }^{47}$

\section{Healing processes and rituals}

Healing is participatory in FoU. The sick person is not a passive recipient of healing and wellness, but a co-producer of health. Healing occurs in stages, the first of which is a form of self-auditing, in which a member is required to write down on a sheet of paper all his or her sins or failings. It is a scribal confession of sin, unlike the oral or verbal confession of sin practised in the Catholic Church. The health-seeker

43 Interview with Senior Elder Tuhumwire.

44 Interview with Senior Elder Tuhumwire.

45 Bisaka, Book of God, 23, 29.

46 The Book of God singles out Chwezi as a special class of evil spirits that thwart people's actions and capabilities. Chwezi are believed to be capable of destroying human destinies as specified by God. For traditional religionists, however, the Chwezi are ancestral deities and gods. The attitude of FoU towards Chwezi is similar to how Pentecostal Christians regard traditional gods, divinities and deities. Generally, this category of spiritual entities is consistently demonised and believed to be antithetical to the spiritual and material well-being of the born-again believer.

Bisaka, Book of God, 62. 
begins or activates the process of healing him or herself. Going down into one's inner labyrinth in search of what ought not to be there is necessary, according to FoU doctrine, for healing. "The goodness of one's soul is what is required of him to get the gift of being healed. There is no asking of one's name, tribe, race or religion. The person who refuses to give up his wickedness is the one who is segregating himself from the others." 48 A person can become sick from refusing to confess serious sins and shortcomings or from refusing to ask for forgiveness. Because of this understanding, the first act of healing is a voluntary and secret confession of one's sins, weaknesses and failings. ${ }^{49}$ By writing one's sins on a paper, which is later dropped in a wooden box next to an entrance post, the member creates a distance between self and non-self. The sins as mystical sources of illness are the non-self that a member wants to get rid of. The paper with the written sins is later dropped in a wooden box next to the entrance post into the investiture hall. In the second stage, the contents of the box are later incinerated at a nearby firepit, the place of burning. As fire destroys sins, from the crucible rises a new, healthy self. The third stage in the healing ritual is when Bisaka stands next to one of the posts of the entrance to screen every member entering the lush green arena that leads into the hall where members change into the kanzu, ritual gown. He is believed to have the power to mystically identify a person who has not sufficiently repented of their sins or who has failed to fully confess them. He sends such a person back to be tutored and helped to remember their sins and confess them before coming into the arena. This process ensures purity and facilitates the healing process. The fourth and final stage is the physical touch which Bisaka performs on every member while inside the Itambiro. In the last act of the worship service, which lasts for more than eight hours, members line up in semi-circular formation in front of the altar. Bisaka walks around with his staff of office in his left hand and places his outstretched right palm on their foreheads and utters silent prayers or words as he does that. It is a symbolic gesture of the transfer of pure healing energy believed to alleviate the suffering of his followers: "For a person who is being healed by Owobusobozi, He either touches him while praying, or sometimes, without even touching him, just prays, "Oh Lord God of Hosts, drive away such and such a disease from this person." That is why, when we pray to Owobusobozi to intercede with the Lord God of Hosts to heal us of our diseases and to grant us our needs we actually get healed and get the needs." 50

\section{The meaning of health}

According to the scripture of FoU, healing "make[s] people one". ${ }^{51}$ Healing removes inefficiency and distortions in human conduct and restores capability and capacity for action. It is a process of restoring "the good needs" of people. ${ }^{2}$

\footnotetext{
48 Bisaka, Book of God, sec 19.

49 Bisaka, Book of God, sec 18.

50 Bisaka, Book of God, sec 154.

51 Bisaka, Book of God, 6.

52 Bisaka, Book of God, sec 13.
} 
Capabilities are abilities, skills, knowledges, power and relationality which enable persons to engage the world of work in pursuing and realising certain goals in life. Healing is a "gift" that promotes human capability, which is the power to achieve desired ends, either personal or communal. ${ }^{53}$ It is a combination of forces that enables a person to take action. The "inefficiency" which illness brings along with it vitiates capacity, socially, emotionally, physically and cognitively. Hence, the need for the services of Bisaka in fighting it and eradicating it. Physical and cognitive underperformance are some of the liabilities and consequences of sickness. Ill health affects the quality of choices and decisions a person makes. Sickness is expensive emotionally, financially, cognitively and socially. When humans perform optimally, they achieve their God-given potential, realise their destinies and, in so doing, achieve a predestined, divine purpose. Healing restores, maintains, sustains and invigorates the ability of a person to prosecute specific objectives and goals related to a self-interested or self-beneficial overall mission, making "people [to] turn to the Lord God of Hosts who created them". ${ }^{54}$ For FoU, capability is relational. It is not individualistic, as no one is conceived in an atomistic manner. Rather, it is how a person, by performing duties and responsibilities that relate to maintaining community life, achieves one's destiny. By achieving one's destiny the person fulfils a divine purpose - that is, the reason for the Lord God of Hosts creating human life. Healing promotes human flourishing by removing "inefficiencies" found in nature and enabling persons to engage "nine days of work and one day for the Lord". ${ }^{55}$ Healing and health make it possible for human "needs" to be met. ${ }^{56}$

Although the nascent or incipient theology of work of FoU is yet to be fully elaborated, what is clear is that human flourishing is linked intrinsically to capabilities and capacities for work, fulfilling tasks that gradually move a person ever closer to realising their destined state or position in life. Human well-being, therefore, is linked to enhanced capacity for work, performance and relationality, which healing makes possible. The capacity to work, the capability to relate and socialise with others and to participate fully in the practices of FoU are necessary ingredients of and for human flourishing, according to FoU. Healing restores, maintains and sustains the human capability to perform and work optimally to realise desired goals without "inefficiency". Capability, as conceived in FoU, is instrumental; it is desired to achieve a certain destiny, which is its ultimate objective. It is also possible to conceive of capabilities as well-being, an end that makes the living and enjoyment of life possible. For FoU, this possibility is often compromised and negated by the "Tempter" (Omwohya), whom Bisaka is to fight

Bisaka, Book of God, sec 19.

Bisaka, Book of God, sec 20.

Personal interview with Senior Elder Tuhumwire. The argument is often made amongst members of FoU that they are more hardworking than Christians, because the former spend only three days in a month to rest and worship their God, while the latter devote four days to worship.

56 Bisaka, Book of God, sec 154. 
and defeat to make the conditions for human flourishing possible. Such a destined state is believed to be divinely assigned at creation by the Lord God of Hosts, the creator of all things. ${ }^{57}$ In the context and worldview in which FoU was founded and operates, capacity as the ability of a person to achieve her destiny, has an ethical component, a relational content. The sociocultural context is one that emphasises communality and community over individuality and individualism. This vision of Bisaka to restore capacity through healing makes him an enunciator of ethical apocalypticism, a new way of living life directed towards the ethical fulfilment of one's destiny.

The capacity to work and engage fruitfully with the physical environment of humans, in FoU's conceptualisation, means a responsible and respectful stewardship of the land. Hence, the group's reluctance to embark on aggressive exploitation of the land. Members of FoU are frequently admonished to plant cash crops in addition to food crops, such as the eucalyptus tree, an evergreen tree in high demand for the making of pulpwood. While the group has the capacity and frequently gathers several thousand people together for its events, it has shunned the intrusion of corporate entities who use similar events to market their wares, goods, and services.

Sociologically and eschatologically, FoU's theology considers disunity a disease of the social body. Disunity in the sphere of religious ideology and belonging and ethnic identity politics, as well as race, is a source of disharmony, a strong debilitating incompatibility in views, opinions, actions and practices. Disunity distracts from human thriving. This is the reason Bisaka gives for his mission and mandate from the Godhead "healing people everywhere, intending to make people one, meaning that disunity has ended". ${ }^{58}$

Human flourishing, according to the teaching and ritual practices of FoU is conceived in three parts. The first is the healing of bodily and spiritual diseases, removing inefficiencies and encumbrances in human conditions in order to restore and sustain the human capacity to engage gainfully with the world of work; with respect to individuals, these encumbrances may be physiological, spiritual, mystical, or moral. The second part is concerned with getting the healed to relate responsibly and sustainably with the physical environment, working to provide for their material needs. The third part is healing the disease of social and religious disunity in order to actualise human potentials and capabilities. This is the eschatological healing dimension which is the destiny of all humankind; it is also the condition for optimal human flourishing.

57 Hoffmann N and Metz T. 2017. "What can the Capabilities Approach Learn from an Ubuntu Ethics: A Relational Approach to Development Theory", World Development 97:153-164.

Bisaka, Book of God (emphasis in original). 


\section{CONCLUSION}

To understand the popularity of FoU and its healing methods, scribal and tactile, it is important to put the organisation in the context of the inability of the Ugandan postcolonial state to provide its citizens with adequate, accessible, affordable and functional healthcare. The organisation is most popular in the rural areas of western Uganda with underperforming social infrastructures, such as accessible roads and healthcare facilities and professionals. The Ugandan president, Yoweri Museveni, and Owobusobozi are friends; the former provides round the clock (military) security for the latter as well as vehicles and other financial gifts. The organisation takes great pride in this public association of its leadership with the national government, and in return, supports the programmes and policies of the state. According to Bisaka, as Museveni endeavours to provide political healing and unity to the nation, so also, he (Bisaka) provides spiritual and social healing to humanity. ${ }^{59}$ A look at the zeitgeist and the broader environment during which FoU has expanded the fastest, which started during the last decade, is instructive. It coincided with the period when the African postcolonial state formations were, and still are, experiencing the most entrenched problems with religiously-induced violence, prolonged inability to supply the needs of citizens, failures to stem the tidal waves of political and economic uncertainties resulting in many Africans drowning attempting to cross the Mediterranean Sea in ill-equipped dinghy boats. ${ }^{60}$ Religious beliefs, organisations, affiliations and practices impact the human security situation. In the case of Uganda, as David Omona shows, religion has had ambivalent consequences on health and security outcomes of its citizens. ${ }^{61}$ This broad failure of state feeds into the popularity of organisations like FoU taking on functions left behind by collective governance as well as the inability of the state to exercise its constitutional oversight on the claims and practices of religious organisations.

Faith of Unity is a religious movement founded on the central claim of restoring health through a diversity of healing practices. It has achieved mass resonance based on this claim and the fame of its leader and founder, Owobusobozi Bisaka, to provide healing to the sick. In the African conception of life and the world, healing, which is regarded as a gift of the gods, as a restoration of threatened security,

59 Personal communication with Owobusobozi Bisaka by A Ukah, Faith of Unity Headqarters, Kapyemi, Uganda, 23 September 2016.

60 Ukah A. 2019. "Is Religion the Curse/Cause of War? The Political Economy of Religious Conflicts in Africa", in Chitando E and Tarusarira J (eds). Religion and Human Security in Africa. Oxford: Routledge, 17-33. More than 3,100 migrants died in 2017 while more than 1,500 more died in 2018 while attempting to cross the Mediterranean to reach Europe. These were mainly African migrants escaping the harsh economic and political situation in their home countries. See "1500 Migrants Have Died in the Mediterranean in 2018, Italy Deadliest Route - UN", Reuters, 27 July 2018.

61 Omona AD. 2019. "Religion and Human Security in Uganda", in Chitando and Tarusarira (eds), Religion and Human Security in Africa, 139-157; Kaczyński GJ. 2012. "Religious Movements in Africa as Expression of the Sacred Trauma: The Explanatory Approach Reconsidered", Hemispheres: Studies on Cultures and Societies 27:5-19. 
destabilised identity and shattered relationships, is very appealing. ${ }^{62}$ According to the teaching of the group, healing restores the sick to full human functioning and optimal capability. This conception of health as the optimal capacity to work is materialistic and this-worldly. In this sense, the teaching of FoU is close to indigenous African conceptions of the goods of religion or salvation, which are health, wealth and children, "health, fertility, protection against witchcraft and danger, guidance, prosperity, and success - in sum, that state of all-round well-being". ${ }^{63}$ The FoU doctrine about healing has no otherworldly components. The capacity to work and fulfil one's destiny is restricted to what is possible in this world. This is problematic in many ways. For example, the absence of otherworldly aspirations is capable of breeding despondency in some people. Death and afterlife are themes rarely broached, shrouded in murkiness or rarely talked about with any clarity. Secondly, the excessive focus on healing and the details about the causes of illness may produce paranoia regarding human vulnerability to mystical harm or attacks. Harmful spirits and evil deities seem to have more power to override human agency, decisions and purpose. Furthermore, in FoU of scheme of reckoning, chance plays a limited role in the sources of illness and misfortune. Still, the possibility of full health producing negative outcomes is also ignored. Healthy humans do not always and consistently engage in productive work. To attribute such negative consequences of "human work" to evil spirits or indigenous deities neglects a significant aspect of human experience of pain, evil, and ontological limitation.

Perhaps, a most difficult challenge to the conception and practice of healing in FoU is its inherent attachment to the person and divinity of Owobusobozi Bisaka. He alone heals. Even though the sick begin the process of healing by writing down their sins and incinerating the paper later, ultimate healing is the unique prerequisite of Bisaka. The provision of healing is a charisma attached to the person, rather than office. In his capacity and function as healer, he has no assistant, no deputy, no equal. As Owobusobozi, he is unable to delegate duties to others. Because healing occurs by his inherent powers, his healing capabilities are non-transferable. In fact, he does not occupy an office; he is the office. Additionally, when healing fails - as it often does - the sick is believed to be responsible for their illness, because they are thought to still be harbouring some unconfessed and unrepented sins. How the community and organisation of FoU resolve the dilemma of personalisation of healing power beyond the founder and leader is yet to be seen. The healing brand of FoU will need to be rethought or routinised in a post-charismatic period yet to come.

62 Magesa L. 1997. African Religion: The Moral Traditions of Abundant Life, Maryknoll, NY: Orbis Books, 52-53; Sogolo G. 1993. Foundations of African Philosophy: A Definitive Analysis of Conceptual Issues in African Thought. Ibadan: Ibadan University Press; Westerlund D. 2006. African Indigenous Religions and Disease Causation: From Spiritual Beings to Living Humans. Leiden: Brill.

63 Peel JDY 2016. Christianity, Islam, and Orișa Religion: Three Traditions in Comparison and Interaction. California: University of California Press, 79. 